Relations industrielles

Industrial Relations

\title{
Le rapport Waisberg
}

\section{Gérard Hébert}

Volume 30, numéro 1, 1975

URI : https://id.erudit.org/iderudit/028587ar

DOI : https://doi.org/10.7202/028587ar

Aller au sommaire du numéro

Éditeur(s)

Département des relations industrielles de l'Université Laval

ISSN

0034-379X (imprimé)

1703-8138 (numérique)

Découvrir la revue

Citer cet article

Hébert, G. (1975). Le rapport Waisberg. Relations industrielles / Industrial

Relations, 30(1), 112-114. https://doi.org/10.7202/028587ar

Tous droits réservés (C Département des relations industrielles de l'Université Laval, 1975
Ce document est protégé par la loi sur le droit d'auteur. L’utilisation des services d'Érudit (y compris la reproduction) est assujettie à sa politique d'utilisation que vous pouvez consulter en ligne.

https://apropos.erudit.org/fr/usagers/politique-dutilisation/ 


\section{COMMENTAIRES}

\section{Le rapport Waisberg}

\section{Gérard HÉBERT *}

La Commission Waisberg devait enquêter sur certaines pratiques présumément illégales dans les secteurs du plâtre, de la planche murale et des formes à béton de l'industrie de la construction, dans les régions de Toronto, Hamilton et Ottawa. Formée le 28 mars 1973, la Commission a remis son rapport en décembre 1974.

Le rapport présente d'abord une description détaillée des secteurs à l'étude, syndicats et entreprises, sans oublier les multiples interrelations d'intérêt qui existent entre plusieurs entreprises impliquées. Les chapitres suivants $(2,3$ et 4$)$ contiennent un exposé circonstancié, souvent par la transcription des témoignagegs et la reproduction des pièces, des principaux actes de violence et de fraude, intervenus entre 1968 et 1973 et qui avaient provoqué l'enquête : incendies, dommage à la propriété, attaques à la dynamite, assauts sur la personne, menaces, paiements illégaux, fixation des prix, etc. Il en ressort certaines descriptions fascinantes et quelques portraits hauts en couleur.

Dès le début du second chapitre, le Juge Waisberg déclare : "Ces événements ne se sont pas produits en réponse à de la provocation, ni dans le vide. Ils sont reliés, dans le temps et les lieux, à la concurrence entre employeurs et entre syndicats, et aux conflits entre employeurs et syndicats $\gg($ p. 32). Aussi le Juge consacre-t-il son dernier chapitre à divers aspects des relations patronales-syndicales : méthodes d'embauche, conflits de juridiction, fonds de bien-être, etc.

De tout cela, le Juge Waisberg tire 4 conclusions et 17 recommandations. D'abord les autorités judiciaires devront prendre les poursuites qui s'imposent suite aux révélations de l'enquête. De plus, il faudrait un contrôle plus sévère des armés et des explosifs. Sur le plan des relations

* Hébert, Gérard, professeur, École des relations industrielles, Université de Montréal, Montréal.

Report of the Royal Commission on Certain Sectors of the Building Industry. Judge Harry Waisberg, Commissioner. Volume One : Report. Volume Two : Appendices. Published by the Minister of the Attorney General. Toronto, Quenn's Printer for Ontario, c. 1974, vol. I : 344 p.; vol. II : 426 p. 
patronales-syndicales, le rapport se limite à formuler des suggestions pour susciter de nouvelles discussions, parce que le problème atteint toute l'industrie et que l'enquête ne portait que sur certains secteurs (p. 342-344).

Quelques suggestions formulent des objectifs indiscutables : les dispositions de la loi doivent être appliquées en fonction de l'intérêt public (3) ; il faut aborder les relations de travail avec une approche dynamique (17). D'autres se rapportent à des points très particuliers, comme la nomination d'un vice-président permanent de la Commission des relations de travail pour les cas de la construction (10) et celle d'un procureur ayant droit de poursuite (15). Retenons plutôt les recommandations d'ordre général. La première traite d'une licence obligatoire pour les entrepreneurs et les sous-traitants « en vue de bien définir les personnes et organisations responsables ». Au Québec, un premier projet de loi de cette nature avait été proposé en 1960, présenté en 1969 mais jamais adopté.

Une autre recommandation vise les unités de négociation : il faut, dit le Juge, en réduire le nombre et «encourager » la négociation multimétiers d'envergure provinciale (14). Le mot peut faire sourire; il ressemble à un voeu pieux. Par contre, l'imposition d'un tel régime ne donnerait pas nécessairement de bons résultats, comme l'a démontré l'expérience du Québec: la négociation multiple s'y est pratiquée tant qu'elle est demeurée libre; depuis qu'elle est obligatoire, en vertu du bill 290, toutes les négociations «officielles» se sont terminées par une décision gouvernementale, les parties ne s'étant pas entendues. Reste à inventer les moyens efficaces d'«encourager » une telle négociation, c'està-dire de placer les parties dans une situation qui les amène à la désirer. La provincialisation des avantages sociaux (pensions et assurances collectives), ainsi que leur transférabilité et contrôle, forment l'objet d'une autre recommandation (8).

La clef des plus graves problèmes de la construction réside dans le régime des bureaux de placement syndicaux ( hiring halls»). A en juger par la description du rapport (p. 327-328), les abus sembleraient moins graves en Ontario qu'au Québec, si on compare à cette description certaines révélations faites davant la Commission Cliche. Le Juge Waisberg recommande seulement que les registres de placement soient ouverts aux employés, aux employeurs et à des «inspecteurs publics»; il souhaite qu'une étude ultérieure soit faite au niveau de toute l'industrie (5). Une mesure aussi timide a-t-elle chance de succès ? Il faudrait que les modalités en soient particulièrement sévères et, plus encore, que les intéressés l'acceptent franchement. On peut souhaiter que la Commission Cliche aille plus loin sur le sujet; il ne faut pas oublier, cependant, qu'il s'agit là d'une institution solidement établie, à laquelle les unions tiennent comme à la prunelle de leurs yeux : elles accepteront difficilement de voir émasculer, encore moins disparaître, l'instrument principal de leur puissance. 
Notons que le tome II contient les annexes au rapport lui-même. D'abord une étude du professeur Woods analyse les caractéristiques des relations de travail dans la construction, en particulier en ce qui a trait aux structures de négociation et aux conflits qui en résultent. Le rapport reproduit ensuite les mémoires soumis à la Commission et les pièces ou exhibits deposés lors des audiences.

\section{Public Sector Bargaining}

\section{A Review of a Report or A Tale of Two Persons}

Public sector bargaining is front and center on the labour relations stage. Action in the private sector drama continues in the wings but in the 1970's the public sector occupies the spot light and commands the attention of the Canadian audience. Unions that were non-existent or relatively unknown ten years ago are now among the largest in the country. Employees who have never previously hit the bricks, and some who have traditionally been opposed to unionism, now find themselves using militant threats and strike tactics.

The Public Service Alliance of Canada, representing mostly nonprofessional employees in the Federal public service, did not exist ten years ago. It is now the third largest union in Canada. During the same period the Canadian Union of Public Employees more than doubled its membership and seems likely to become the largest union in the country. Nurses (at least in New Brunswick) have been blowing out the Florence Nightingale lamp. Early in 1975, in an attempt to renegotiate wage scales in an unexpired collective agreement, they submitted resignations in large numbers and voted to defy a Supreme Court injunction to return to the hospitals. Strikes by school teachers are no longer a rare or strange event; and professors at several universities have been seeking certifications and bargaining relationships with their governing boards. Letter carriers and postal clerks, meat inspectors and grain inspectors, air traffic controllers and airport firemen - how often did they occupy the attention of headline hunters ten years ago ? Only an exceptionally obtuse observer could fail to see that this extension of bargaining has been the most significant development in Canadian labour relations since the rapid growth of industrial unions some thirty years earlier.

Not surprisingly there has been a parallel growth in published writings about public sector bargaining in Canada. In 1965 they scarcely existed. Beyond the study by S. Frankel and C. Pratt on Municipal Labour

* W. B. Cunningham, Head, Department of Economics and Political Science, Mount Allison University, Sackville, N. B. 